\title{
Postpartum sacral stress fracture: a case report
}

Nadeen Hilal ${ }^{1,2}$ and Anwar H. Nassar ${ }^{3^{*}}$

\begin{abstract}
Background: Stress fractures are classified as insufficiency and fatigue fractures. Insufficiency fractures occur when normal stresses are placed on bone with decreased mineralization and elastic resistance; whereas fatigue fractures occur when abnormal forces are applied to normal bone.

Case presentation: We report a case of postpartum bilateral sacral fracture in the absence of documented osteoporosis in a 30 year old Lebanese female, thus satisfying the classification of fatigue fractures. Clinical presentation was mainly low back pain, pelvic pain, and abnormal gait.

Conclusions: This case stresses the importance of including sacral fractures in the differential diagnosis of patients presenting with similar symptoms during pregnancy or the postpartum period.
\end{abstract}

Keywords: Stress fracture, Sacrum, Postpartum, Back pain, Pregnancy

\section{Background}

Stress fractures are classified as insufficiency and fatigue fractures. Insufficiency fractures occur when normal stresses are placed on bone with decreased mineralization and elastic resistance; whereas fatigue fractures occur when abnormal forces are applied to normal bone, such as in tibial stress fractures in long distance runners [1]. Stress fractures occur secondary to repeated cyclic loading that eventually exceeds elastic resistance of bone [1].

Sacral insufficiency fractures were first recognized by Lourie in 1982 as a "distinct clinical entity of spontaneous osteoporotic fracture of the sacrum" [2]. Since their identification, several patient populations were found to be at increased risk. These include: the elderly, patients with weak bones from radiation therapy, and those with dysplastic, neoplastic, congenital, metabolic, or endocrine diseases [3].

Few cases of postpartum sacral fractures have been reported in the literature. Some cases were classified as insufficiency fractures [4] while others as fatigue fractures $[2,5-10]$. In some cases, the authors were not sure if they were dealing with insufficiency or fatigue fractures

\footnotetext{
* Correspondence: an21@aub.edu.lb

${ }^{3}$ Department of Obstetrics and Gynecology, American University of Beirut Medical Center, PO Box: 11-0236, Riad El Solh, Beirut 1107 2020, Beirut, Lebanon

Full list of author information is available at the end of the article
}

[11-15]. We report a case of postpartum bilateral sacral fracture in the absence of documented osteoporosis.

\section{Case presentation}

A 30-year-old gravida 1, para 1 presented because of bilateral buttocks and low back pain that started 10 days postpartum. The pain was dull in nature, was more severe on the right side, and was progressively increasing in intensity resulting in a limping gait. Pain worsened with walking, bending, and minor activity and was partially relieved with rest. Patient self-prescribed analgesics and non-steroidal anti-inflammatory drugs (NSAIDs) which used to relief pain transiently.

The patient is otherwise healthy with no history of metabolic bone disease, menstrual irregularities, previous fractures, eating disorders, or strenuous athletic activity. No family history of osteoporosis was reported. The course of pregnancy was smooth with no remarkable back, hip, or buttocks pain reported. The total weight gained during pregnancy was $14 \mathrm{~kg}$. She was maintained on supplemental iron, calcium (1000 mg daily), and vitamin D (800 international units (IU)) daily as of the second trimester. At term, she presented in labor and received epidural anesthesia. The first stage of labor was $7 \mathrm{~h}$ and second stage was $100 \mathrm{~min}$. She had an uneventful, spontaneous, normal vaginal delivery without the need for 
forceps or vacuum application. The baby was healthy and weighed $3350 \mathrm{~g}$.

Two weeks after onset of her symptoms, the patient sought medical attention because of persisting pain and abnormal gait. On physical exam, the patient was of average body habitus with height $164 \mathrm{~cm}$ and weight $60 \mathrm{~kg}$. Mobility of the lumbosacral spine was within normal limits. Tenderness around the upper gluteal region and sacrum was noted bilaterally; more evident on the right side.

Pelvic magnetic resonance imaging (MRI), performed to rule out soft tissue lesions, demonstrated moderate-tosevere bone marrow edema involving the right sacrum along its entire length with a non-displaced fracture line. Mild edema was also seen involving the left sacrum. Results of the MRI are displayed in Fig. 1a and b.

Dual-energy X-ray absorptiometry was performed to rule out pregnancy-associated osteoporosis. It revealed normal lumbar spine and left forearm mineral densities with low normal values at the femur bone (Table 1). Basic metabolic workup including complete blood count, thyroid stimulating hormone, parathyroid hormone, vitamin D, serum calcium, and urinary calcium levels were normal.

Patient was treated with relative rest, analgesics, and NSAIDs. Empirically, and based on no solid evidence, she was also given oral vitamin D (50,000 IU per week) and calcium ( $1 \mathrm{~g}$ daily) supplementation to facilitate and fasten bone healing. Breastfeeding was not interrupted. Vitamin D was continued for a total of 4 months. One month later, patient symptoms started to improve gradually requiring less pain medications. Pain completely resolved and gait was restored around 6 months postpartum. No follow up MRI was performed and the patient was considered to have a healed fracture based on resolution of her symptoms.

To note, after 5 months of the diagnosis of sacral fractures, the patient underwent a follow up dual-energy X-ray absorptiometry. This study was performed as a follow up after improvement of symptoms and as a baseline before a planned second pregnancy. The results are outlined in Table 1.

\section{Discussion}

This article presents a case of postpartum spontaneous sacral fracture in the absence of documented osteoporosis. Risk factors for sacral stress fractures during pregnancy or in the first weeks postpartum include vaginal delivery of large for gestational age infants, increased lumbar lordosis, excessive weight gain and a rapid vaginal delivery (precipitous labor) [16]. Other risk factors include vitamin D deficiency, anticoagulant therapy with heparin and transient osteoporosis associated with pregnancy and lactation. Our patient did not suffer from any of those risk factors. Since all the workup done including dual-energy X-ray absorptiometry was normal; the fracture can be classified as a sacral fatigue fracture. However, there is a high probability that we might have been dealing with a case of pregnancyassociated osteoporosis due to two reasons. The first one is the result of the first dual-energy $\mathrm{X}$-ray absorptiometry that was performed 5 weeks postpartum. The International Society for Clinical Densitometry recommends the use of BMD Z-scores in premenopausal women, where a Z-score of lower than -2.0 should be interpreted as "below the expected range for age" [17]. Thus, despite the fact that the results do not fulfill criteria of low bone density $(Z$ score $<-2)$ in premenopausal women, it is evident that the bone density is borderline low, especially at the femur where $\mathrm{Z}$ score was - 1.9. Thus, there might be a possibility that these numbers were lower during pregnancy and the immediate postpartum period and have already started to correct by the time the study was done. Another reason is that the follow up dual-energy X-ray absorptiometry that was performed 5 months later revealed an increase in the bone density at the spine and femur. Densitometry
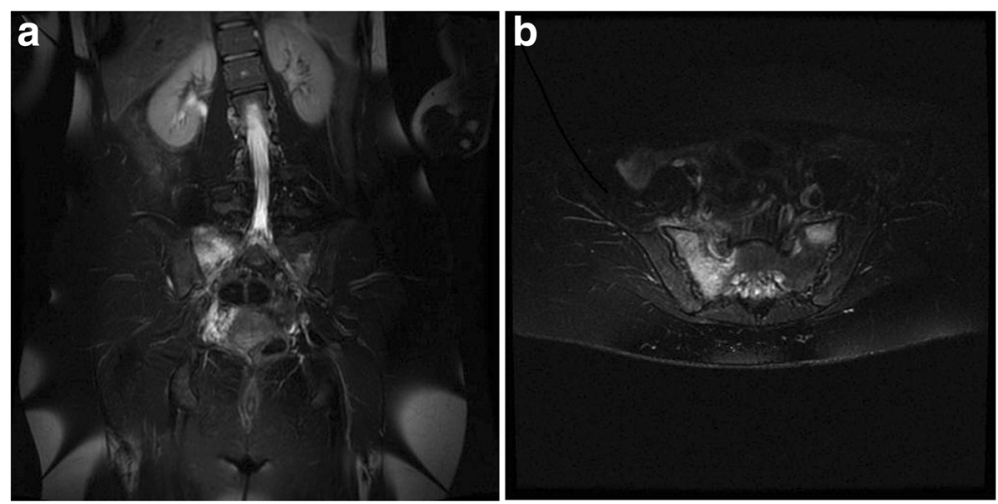

Fig. $1 \mathrm{MRI}$ of pelvis. a coronal T2 demonstrating bone marrow edema with non-displaced fracture line on right sacrum. b axial T2 demonstrating bone marrow edema in both sacral bones 
Table 1 Results of Dual-energy X-ray Absorptiometry

\begin{tabular}{lllll}
\hline Skeletal region & $\begin{array}{l}\text { Bone density at } \\
\text { diagnosis of fracture } \\
\left(\mathrm{g} / \mathrm{cm}^{2}\right)\end{array}$ & $\begin{array}{l}\text { Bone density at follow } \\
\text { up after } 5 \text { months } \\
\left(\mathrm{g} / \mathrm{cm}^{2}\right)\end{array}$ & $\begin{array}{l}\text { SD above or below } \\
\text { the mean for young } \\
\text { adults at diagnosis } \\
\text { of fracture (Z score) }\end{array}$ & $\begin{array}{l}\text { SD above or below the } \\
\text { mean for young adults at } \\
\text { follow up after } 5 \text { months } \\
(Z \text { score })\end{array}$ \\
\hline $\begin{array}{l}\text { Spine (L1-L4) } \\
\text { Femur: Total }\end{array}$ & 0.875 & 0.878 & -1.6 & -1.5 \\
Neck & 0.706 & 0.733 & -1.9 & -1.7 \\
Forearm & 0.642 & 0.684 & -1.9 & -1.5 \\
\hline
\end{tabular}

${ }^{\mathrm{a}} S D$ standard deviation, ${ }^{\mathrm{b}} \mathrm{NA}$ not available

measurement of the forearm was not repeated. Another reason why this case can be regarded as a complication of pregnancy-associated osteoporosis is the timing of the event, which occurred in the immediate postpartum period; the affected skeletal region being the spine; and the lack of other reasons or risk factors for fractures. However, the possibility of pregnancy-associated osteoporosis remains a hypothesis that cannot be fully proven in this case.

\section{Conclusion}

Since their initial description, little knowledge has been added concerning the pathogenesis, patient population, clinical manifestations, diagnostic techniques, and treatment options of sacral stress fractures. Thus, they have remained an unexplored clinical entity and are likely a frequently underdiagnosed cause of low back or pelvic pain. This case and similar cases previously reported suggest that sacral stress fractures should be considered in the differential diagnosis of low-back pain, buttock pain, and abnormal gait during pregnancy and the postpartum period. Delays in the diagnosis might be very painful for the women affected.

\section{Ethics approval and consent to participate Not applicable.}

\section{Consent for publication}

Written informed consent was obtained from the patient for publication of this case report and any accompanying images. A copy of the written consent is available for review by the Editor of this journal.

\section{Availability of data and materials Not applicable.}

\section{Abbreviations}

IU: international units; MRI: magnetic resonance imaging; NSAIDS: nonsteroidal anti-inflammatory drugs.

\section{Competing interests}

The authors declare that they have no competing interests.

\section{Authors' contributions}

$\mathrm{NH}$ wrote the case report and part of the discussion. In addition, she was the endocrinology fellow involved in the management of the patient and AN wrote the discussion, edited the paper and was the obstetrician managing the patient. Both authors read and approved the final manuscript.

\section{Acknowledgements}

This case report did not require funding. No other acknowledgements are to be made.

\section{Funding}

Not applicable.

\section{Author details}

'Department of Internal Medicine, American University of Beirut Medical Center, Beirut, Lebanon. ${ }^{2}$ Ain Wazein Hospital, Ain Wazein, Lebanon. ${ }^{3}$ Department of Obstetrics and Gynecology, American University of Beirut Medical Center, PO Box: 11-0236, Riad El Solh, Beirut 1107 2020, Beirut, Lebanon.

Received: 22 May 2015 Accepted: 18 April 2016

Published online: 30 April 2016

\section{References}

1. Lin JT, Lane JM. Sacral stress fractures. J Womens Health (Larchmt). 2003;12(9):879-88.

2. Lourie H. Spontaneous osteoporotic fracture of the sacrum: an unrecognized syndrome of the elderly. JAMA. 1982;248(6):715-7.

3. Karataş M, Basaran C, Ozgül E, Tarhan C, Ağildere AM. Postpartum sacral stress fracture-an unusual case of low-back and buttock pain. Am J Phys Med Rehabil. 2008;87(5):418-22.

4. Breuil $V$, Brocq O, Euller-Ziegler $L$, Grimaud A. Insufficiency fracture of the sacrum revealing a pregnancy associated osteoporosis: first case report. Ann Rheum Dis. 1997;56(4):278-9.

5. Sibilia J, Javier RM, Werle C, Kuntz JL. Fracture of the sacrum in the absence of osteoporosis of pregnancy: a rare skeletal complication of the postpartum. Br J Obstet Gynaecol. 1999;106(10):1096-7.

6. Rousière M, Kahan A, Job-Deslandre C. Postpartal sacral fracture without osteoporosis. Joint Bone Spine. 2001:68(1):71-3.

7. Narvaez J, Narvaez JA. Post-partal sacral fatigue fracture. Rheumatology (Oxford). 2003;42(2):384-5.

8. Lin JT, Lutz GE. Postpartum sacral fracture presenting as lumbar radiculopathy: a case report. Arch Phys Med Rehabil. 2004;85(8):1358-61.

9. Thein R, Burstein $G$, Shabshin N. Labor-related sacral stress fracture presenting as lower limb radicular pain. Orthopedics. 2009:32(6):447.

10. Celik EC, Oflouglu D, Arioglu PF. Postpartum bilateral stress fractures of the sacrum. Int J Gynaecol Obstet. 2013;121(2):178-9.

11. Schmid L, Pfirrmann C, Hess T, Schlumpf U. Bilateral fracture of the sacrum associated with pregnancy: a case report. Osteoporos Int. 1999;10(1):91-3.

12. Hoang TA, Nguyen TH, Daffner RH, Lupetin AR, Deeb ZL. Case report 491: stress fracture of the right sacrum. Skeletal Radiol. 1988;17(5):364-7.

13. Thienpont E, Simon JP, Fabry G. Sacral stress fracture during pregnancy-a case report. Acta Orthop Scand. 1999;70(5):525-6. 
14. Dussa CU, El Daief SG, Sharma SD, Hughes PL. Atraumatic fracture of the sacrum in pregnancy. J Obstet Gynaecol. 2005;25(7):716-7.

15. Beltran LS, Bencardino JT. Lower back pain after recently giving birth: postpartum sacral stress fractures. Skeletal Radiol. 2011;40(4):461-2. 481-2.

16. Longhino V, Bonora C, Sansone V. The management of sacral stress fractures: current concepts. Clin Cases Miner Bone Metab. 2011;8(3):19-23.

17. The International Society for Clinical Densitometry. 2015 ISCD official positions-adult. 2015. Can be accessed at: http://www.iscd.org/officialpositions/2015-iscd-official-positions-adult/. Accessed 25 Apr 2016.

Submit your next manuscript to BioMed Central and we will help you at every step:

- We accept pre-submission inquiries

- Our selector tool helps you to find the most relevant journal

- We provide round the clock customer support

- Convenient online submission

- Thorough peer review

- Inclusion in PubMed and all major indexing services

- Maximum visibility for your research

Submit your manuscript at www.biomedcentral.com/submit 